\title{
Evidência do cão como reservatório da leptospirose humana: isolamento de um sorovar, caracterização molecular e utilização em inquérito sorológico
}

\author{
Evidence of dog as a reservoir for human leptospirosis: a serovar isolation, \\ molecular characterization and its use in a serological survey
}

\author{
Claudiomar Soares Brod", José Antonio Guimarães Aleixo², Sandra Denise Dorneles \\ Jouglard $^{2}$, Cláudia Pinho Hartleben Fernandes ${ }^{1}$, José Luís Rodrigues Teixeira ${ }^{1}$ \\ e Odir Antônio Dellagostin ${ }^{2}$
}

\begin{abstract}
RESUMO
A leptospirose canina é conhecida como enfermidade de Stuttgard desde 1898, sendo os cães, depois dos roedores, considerados como a segunda principal fonte de infecção para o homem. 0 isolamento de um sorovar patogênico da urina de um cão, laboratorial e clinicamente identificado como tendo leptospirose, e sua utilização para testar amostras de soro de casos de leptospirose humana e canina, evidenciou a sua importância no ecossistema da região sul do Brasil. Os resultados do teste de soroaglutinação microscópica indicaram que 100\% das amostras de soro humano de 12 pacientes do banco de soro de 2001 do Centro de Controle de Zoonoses, que haviam reagido com títulos que variaram de 25 a 3.200 para 0 sorovar canicola, e 72\% das amostras de 105 soros caninos do mesmo banco de soro, também reagiram contra 0 novo isolado. 0 título médio e mediana dos soros humanos testados com a bateria de antígenos recomendada pela OMS, foi respectivamente 630 e 100, ao passo que os testados com o isolado foi de 1.823 e 400 . Nos soros caninos, os títulos foram respectivamente de 347 e 100 para a bateria e de 1.088 e 200 para 0 isolado.
\end{abstract}

Palavras-chaves: Leptospira. Isolamento. PCR. Sorologia.

\begin{abstract}
Canine leptospirosis has been known as Stuttgart disease since 1898, and dogs are considered to be the second principal source of infection in man. The isolation of a pathogenic serovar from dog urine that was diagnosed clinically and laboratorial as having leptospirosis and its utilization to test serological samples of human and canine cases of leptospirosis, has demonstrated its importance to the ecosystem of the southern region of Brazil. The results of the serological microscopic agglutination test indicated that 100\% of human serum samples from 12 patients from the serum bank of 2001 at the Center for Control of Zoonoses, that had titers between 25 and 3,200 with the canicola serovar, and $72 \%$ of 105 canine serum samples from the same serum bank, also reacted with the new isolate. The mean and median titers of the human serum samples tested with the battery of antigens recommended by WHO was 630 and 100 respectively, and when tested with the isolate it was 1,823 and 400. In the dog sera, the values were respectively 347 and 100 with the battery, and 1,088 and 200 with the isolate.
\end{abstract}

Key-words: Leptospira. Isolation. PCR. Serology.

\footnotetext{
1. Centro de Controle de Zoonoses da Faculdade de Veterinária da Universidade Federal de Pelotas, Pelotas, RS. 2. Centro de Biotecnologia da Universidade Federal de Pelotas, Pelotas, RS.

Endereço para correspondência: Prof. Claudiomar Soares Brod. Centro de Controle de Zoonoses/UFP. Campus Universitário. Prédio nํ42, 96010-900 Pelotas, RS. Tel: 5553 3275-7307; Fax: 5553 3275-7551

e-mail: clauhart@ terra.com.br

Recebido em 14/12/2002

Aceito em 16/4/2005
} 
Infecções com Leptospira interrogans foram reconhecidas pela primeira vez no Brasil, em 1917, no Paraná21. Em 1930, foi identificado o primeiro caso de leptospirose humana ocorrido na Cidade de São Paulo, onde o sangue do paciente foi inoculado em cobaios, reproduzindo-se experimentalmente a doença ${ }^{25}$. № Rio de Janeiro, em 1940, 11 cães com manifestações clínicas compatíveis com leptospirose foram submetidos à necropsia para confirmar a presença do agente causador da leptospirose em cães no Brasil ${ }^{8}$. Em 1954, descreveu-se um caso de febre canicola humana, relacionando o sorovar canicola ao contato com os cães, que seriam freqüentemente infectados por este agente ${ }^{32}$.

Os cães são os hospedeiros do sorovar canicola e, em populações não vacinadas, a incidência de infecção por este sorovar pode ocorrer de 50 a $75 \%{ }^{5}$. Os ratos são os hospedeiros do sorovar icterohaemorrhagiae, mas os cães são freqüentemente hospedeiros acidentais deste agente ${ }^{29}$.

Ainclusão de cepas de leptospira, isoladas dos locais onde há ocorrência de casos, na bateria de antígenos padrão para diagnóstico, a qual é constituída de isolados de diferentes ecossistemas e distribuída pela OMS, justifica-se pelo aumento na especificidade e sensibilidade do teste de aglutinação microscópica (MAT), devido à particularidade antigênica entre as cepas de Leptospira patogênica. Na Índia, no ano de 2000, após 0 isolamento de 296 espiroquetas de 1348 culturas de rins de quatro espécies de roedores, foi recomendada a inclusão da L inadai, espécie identificada em maior número, na bateria de antígenos leptospirais usada para estudos soroepidemiológicos ${ }^{1013}$.

№ Município de Pelotas, a avaliação da prevalência e fatores de risco à leptospirose canina, identificou a prevalência de 28,9\% em cães domiciliados, sendo predominante as reações para os sorovares canicola e icterohaemorrhagiae. 0 mesmo estudo conclui que cães mantidos em pátios abertos apresentaram risco duas vezes maior para contrair a doença e a ausência de esgoto na residência dos proprietários dos cães foram os principais fatores de risco à leptospirose ${ }^{12}$. Estudo semelhante, realizado na zona rural do Município de Pelotas, identificou os sorovares icterohaemorrhagiae, copenhageni, australis e canicola como os mais freqüentes. Neste estudo, o contato dos cães com açudes, banhados e a localização dos animais em propriedades com altitudes inferiores a $100 \mathrm{~m}$ foram os principais fatores de risco à leptospirose canina ${ }^{17}$.

Na área de abrangência do Centro de Controle de Zoonoses de Pelotas (CCZ-Pelotas), a análise de 425 amostras de soros de cães errantes, evidenciou a prevalência de 34,8\% de leptospirose canina, sendo os sorovares canicola e icterohaemorrhagiae os mais freqüentes. A prevalência da doença, naquele período, esteve diretamente associada aos fatores climáticos de temperatura elevada e alta precipitação pluviométrica; biológicos, pela presença de reservatórios domésticos e/ou silvestres nos locais de ocorrência de casos; e pelo fator econômico-social. Estes três fatores associados foram importantes para a manutenção das leptospiras no ambiente e conseqüentemente para a ocorrência da infecção canina, podendo ocorrer infecção do homem ${ }^{3}$.

Quanto ao estudo da leptospirose humana realizado através da MAT, de 386 amostras de soros de trabalhadores do serviço de saneamento ambiental do Município de Pelotas, ocorreu a prevalência de 10,4\% de soros reagentes. Este resultado comprova que profissionais envolvidos com esse tipo de atividade apresentam alto risco de contrair leptospirose, devido ao contato direto com ambientes contaminados por urina de roedores $\mathrm{e}$ carnívoros domésticos ${ }^{1}$. Em relato de cinco casos clínicos, de pacientes internados no Hospital Universitário de Rio Grande, quatro pacientes apresentaram síndrome de Weil e um caso oligossintomático e anictérico. Os pacientes apresentaram leptospiremia, leptospirúria e sorologia positiva para os sorovares pomona, icterohaemorrhagiae e bataviae. Porém, em um caso de síndrome de Weil o soro não foi reagente na MAT e somente foi identificada leptospiremia e leptospirúria ${ }^{24}$. A presença de espiroquetas foi constatada em 196 amostras de soro de pacientes suspeitos de leptospirose, sendo que 196 apresentavam espiroquetas no sangue e destes somente 166 apresentaram correspondência de anticorpos ${ }^{11}$, tanto no teste de aglutinação macroscópica ( SAT) e/ou na de aglutinação microscópica (MAT) com antígenos vivos.

Devido à controvertida interpretação diagnóstica em casos de leptospirose e da recomendação da utilização de cepas locais no diagnóstico, descreve-se neste trabalho, 0 isolamento de um sorovar de L interrogans, sua caracterização sorológica e molecular e seu desempenho na detecção de anticorpos antileptospira em uma bateria de soros humanos e caninos suspeitos de leptospirose.

\section{MATERIAL E MÉTODOS}

Caso clínico. Um cão SRD, de nome Tande, macho, com 4 anos de idade, pesando $9 \mathrm{~kg}$, procedente de uma clínica veterinária do Município de Pelotas, apresentava temperatura de $40^{\circ} \mathrm{C}$, dificuldade de movimentação do trem posterior, apatia, anorexia, dor à palpação abdominal e dos membros posteriores. Foi realizado tratamento antipirético e antiinflamatório. No segundo dia, 0 animal obteve melhora acentuada, com movimentação normal e apetite recuperado. No terceiro dia, após consumo de alimento enlatado, 0 cão apresentou vômito, sendo então preconizado antiemético. № oitavo dia, ocorreu diarréia com sangue e vômito de cor amarelada, sendo administrado reconstituinte da microbiota intestinal e antiemético. № nono dia, ocorreu melhora do estado geral, sendo mantido tratamento por mais dois dias. No décimo quarto dia, 0 animal apresentou salivação sangüinolenta, necrose de toda a borda da língua, desidratação moderada e temperatura de 39ำ. Foi procedida a hospitalização do animal e envio de amostra de urina para o CCZ. Neste momento, foi iniciada a antibióticoterapia com penicilina $\mathrm{G}$ potássica, penicilina $\mathrm{G}$ procaínica e dihidroestreptomicina; soroterapia com Ringer com lactato e solução de própolis em spray. № décimo quinto dia, foi enviada amostras de sangue heparinizado para o CCZ. No décimo sexto dia, 0 cão apresentou melhora, com a língua em processo de cicatrização avançado. No décimo nono dia, após cinco dias de hospitalização, com respostas positivas ao tratamento e estado geral próximo ao normal, 0 cão apresentou hematúria, 
dor à palpação abdominal e ataxia dos membros posteriores pelo período da manhã; taquipnéia e taquicardia à tarde $\mathrm{e}$ óbito às 22 horas.

Pesquisa direta de espiroquetas no sangue, em microscopia de campo escuro (BDFM). Foi realizada a pesquisa de espiroqueta no sangue heparinizado, após centrifugação a 3.000 x g por 5 minutos. Foram examinados $5 \mu \mathrm{l}$ do sobrenadante entre lâmina e lamínula (18X18mm), utilizando-se objetivas de 40X, ocular de 15X e condensador de campo escuro a seco. A visualização de uma ou mais espiroquetas com morfologia e movimentação características, indicava diagnóstico positivo.

Pesquisa direta de espiroquetas na urina, em microscopia de campo escuro (UDFM). As amostras de urina coletadas em potes estéreis foram centrifugadas a $3.000 \mathrm{x} \mathrm{g} \mathrm{por}$ 5 minutos. Desprezou-se o pellet e centrifugou-se 0 sobrenadante a $14.000 \mathrm{x} \mathrm{g} \mathrm{a} 5^{\circ} \mathrm{C}$ por 20 minutos. Desprezouse 0 sobrenadante, o pellet foi suspendido em $100 \mu \mathrm{L}$ de PBS $(\mathrm{pH} 7,2)$. Foram examinados $5 \mu \mathrm{l}$, entre lâmina e lamínula (18X18mm), utilizando-se objetivas de 40X, ocular de 15X e condensador de campo escuro a seco. A visualização de uma ou mais espiroquetas com morfologia e movimentação características, indicava diagnóstico positivo.

Inoculação em hamster. Foi inoculado intraperitonealmente, $1 \mathrm{~mL}$ da urina do cão, em quatro hamsters sírio capa dourada, recém-desmamados (20 dias), os quais foram observados diariamente quanto ao aparecimento de sinais clínicos e óbito.

Inoculação em meio de cultura EMJH. Procedeu-se a diluição seriada da urina do cão $\left(10^{-1}\right.$ a $\left.10^{-5}\right)$ em PBS ( pH 7,2 ) e inoculou-se $0,5 \mathrm{~mL}$ de cada diluição em três séries de três tubos contendo $5 \mathrm{~mL}$ dos seguintes meios de cultura líquidos: EMJH enriquecido a 10\% com soro de coelho; EMJH enriquecido a 10\% com albumina bovina e TSB. Também foi inoculada uma série de três tubos de meio EMJH semi-sólido enriquecido com albumina bovina. Os tubos inoculados foram incubados por 24 horas a $37^{\circ} \mathrm{C}$, passando após para estufa a $30^{\circ} \mathrm{C}$, sendo acompanhado 0 crescimento de leptospiras macro e microscopicamente.

Preparação das amostras para PCR. amostra de urina na quantidade de $10 \mathrm{~mL}$ foi centrifugada a $15.000 \mathrm{x}$ g por 20 minutos a 5ำ. 0 pellet lavado duas vezes com $500 \mu \mathrm{L}$ de PBS $(\mathrm{pH} 7,4)$ foi ressuspendido em $50 \mu \mathrm{L}$ de PBS $(\mathrm{pH} 7,4)$ e aquecido a $100^{\circ} \mathrm{C}$ por 10 minutos, para extração do DNA.

PCR. Primers A e $\mathrm{B}^{22}$, correspondendo aos nucleotídeos 38 a 57 e 348 ao 368 na estrutura primária do gene rrs que codifica para o RNA ribossomal 16S de L Interrogans foram utilizados. A reação de PCR foi realizada em um volume final de $25 \mu \mathrm{L}$, contendo $10 \mu \mathrm{L}$ da amostra, $2,5 \mu \mathrm{L}$ de tampão $10 \mathrm{X}$ contendo 2,5mM de $\mathrm{MgCl}_{2}$, 0,5 $\mathrm{LL}$ de dNTP 10mM, 150ng de cada primer e 1 unidade de Taq DNA polimerase (Gibco BRL). Para processar a reação utilizou-se um termociclador Perkin Elmer 2.400 (PE Biosystems) programado para uma desnaturação inicial a $94^{\circ} \mathrm{C}$ por 5 min, seguido de 32 ciclos de desnaturação a $94^{\circ} \mathrm{C}$ por 1 min, anelamento a $55^{\circ} \mathrm{C}$ por 1 min, e polimerização a $72^{\circ} \mathrm{C}$ também por 1 min. Para finalizar, a reação foi submetida a $72^{\circ} \mathrm{C}$ por 7 min. 0 produto da reação de PCR foi submetido à eletroforese em gel de agarose $2 \%$, contendo brometo de etídio $(0,05 \mu \mathrm{g} / \mu \mathrm{L})$, e a visualização foi feita em transiluminador com luz ultravioleta. 0 resultado foi fotografado utilizando-se uma câmera digital Kodak EDAS 40.

Seqüenciamento. Após purificação do produto do PCR com a utilização do kit "GFX'M PCR DNA and Gel Band Purification Kit" (AMERSHAM PHARMACIABIOTECH), seguindo as instruções do fabricante, 0 DNA foi enviado para 0 Centro de Biotecnologia do Instituto Butantan em São Paulo, para ser seqüenciado pelo método de Sanger, utilizando os próprios primers usados no PCR. A reação utilizou a tecnologia do dye terminator em seqüenciador ABI 377 (Applied Biosystems).

Identificação do sorovar. A seqüência parcial do rDNA 16S obtida foi comparada com as seqüências de rDNA 16S de organismos representados na base de dados Genbank (http://www.ncbi.nlm.nlh.gov). Esta comparação foi feita usando BLAST ${ }^{\circledast}$ (Basic Local Alignment Search Tool).

Inquérito sorológico. Para o inquérito sorológico, foi utilizado 0 teste de MAT conforme recomendado ${ }^{10}$, incluindo 52 culturas de leptospiras representantes das espécies genômicas interrogans, borgpetersenii, weilii, kirshneri, noguchii, santarosai, biflexa, illini, fainei e meyeri, constando os sorogrupos Australis, Autumnalis, Ballum, Bataviae, Canícola, Celledoni, Grippotyphosa, Icterohaemorrhagiae, Javanica, Panama, Pomona, Pyrogenes, Sejroe, Shermani, Tarassovi, Andamana, Semaranga, Djasiman, Mini, Illini, Doberdo, Louisiana, Garcia, Nazaré e Pulpudeva. 0 teste foi considerado positivo se a partir de uma diluição de 1:25 fosse encontrado 50\% ou mais do antígeno aglutinado, ou se a densidade do antígeno, no complexo antígeno anticorpo, fosse menor que $50 \%$.

Soros humanos. Foram utilizadas 20 amostras de soro humano reagentes para o sorovar canicola, com títulos que variaram de 25 a 3.200, provenientes do banco de soros do CCZ, ano de 2001.

Soros caninos. Foram utilizados 105 soros caninos do banco de soros 2001 do CCZ, dos quais 52,4\% eram soro reagentes com pelo menos um sorovar da bateria de antígenos para diagnóstico, sendo os sorovares illini, canicola, ballum, e bratislava os mais prevalentes.

\section{RESULTAD0S}

Caso clínico. No exame direto em microscopia de campo escuro da urina do cão, foi constatada a presença de um grande número de espiroquetas. Entre os quatro hamsters inoculados, 2 morreram com 10 dias de inoculação, 1 com 18 dias e 0 outro foi sacrificado no $20^{\circ}$ dia, sendo coletado material ( fígado e rins) para inocular em meios de cultura. Foram isoladas leptospiras em todos os meio de cultura, tanto da semeadura da urina do cão como de fígado e rins dos hamsters, sendo que a melhor adaptação do isolado ocorreu no EMJH enriquecido com 10\% de soro de coelho. A reação sorológica do cão no 15ํdia do curso da enfermidade revelou 
positividade característica de reações paradoxais, com títulos de 25 para 0 sorovar sentot; 50 para hardjo e Buenos Aires; 100 para hurstbridge, hebdomadis e andamana, e 200 para butembo, ballum, castellonis, canicola, copenhageni e sejroe. Logo que se obteve uma densidade do isolado de $2 \times 10^{7}$ leptospiras por $\mathrm{mL}$ (aferida por contagem em câmara de Petroff-Hausser), enfrentou-se 0 mesmo com o soro do próprio animal em uma reação de MAT, não sendo observada reação de aglutinação. provavelmente caracterizando a presença de antígeno superficial "Vi" comum nos isolados recentes, que bloqueia os antígenos superficiais aglutinantes. Na $4^{a}$ passagem do isolado, foi repetida a reação obtendo-se um título de 1.600.
PCR. 0 resultado da reação de PCR mostrou a amplificação de uma banda de 331pb (Figura 1) , correspondente a amplificação do gene que codifica para o RNA ribossomal 16Sde L interrogans.

Seqüenciamento. 0 seqüenciamento pelo método de Sanger do rDNA 16S, quando comparado com as seqüências do GenBank, identificou 100\% de homologia para a Leptospira interrogans sorovar canicola amostra Moulton e para a Leptospira meyeri amostra Bandicoot.

Inquérito sorológico. Soros humanos: das vinte amostras de soro analisadas (Tabela 1) revelaram que nos pacientes 1, 2, 3, 6, 7, 8 e 9 (58,3\%) , o diagnóstico com a bateria normal de antígenos não identificaria 0 título mais alto de

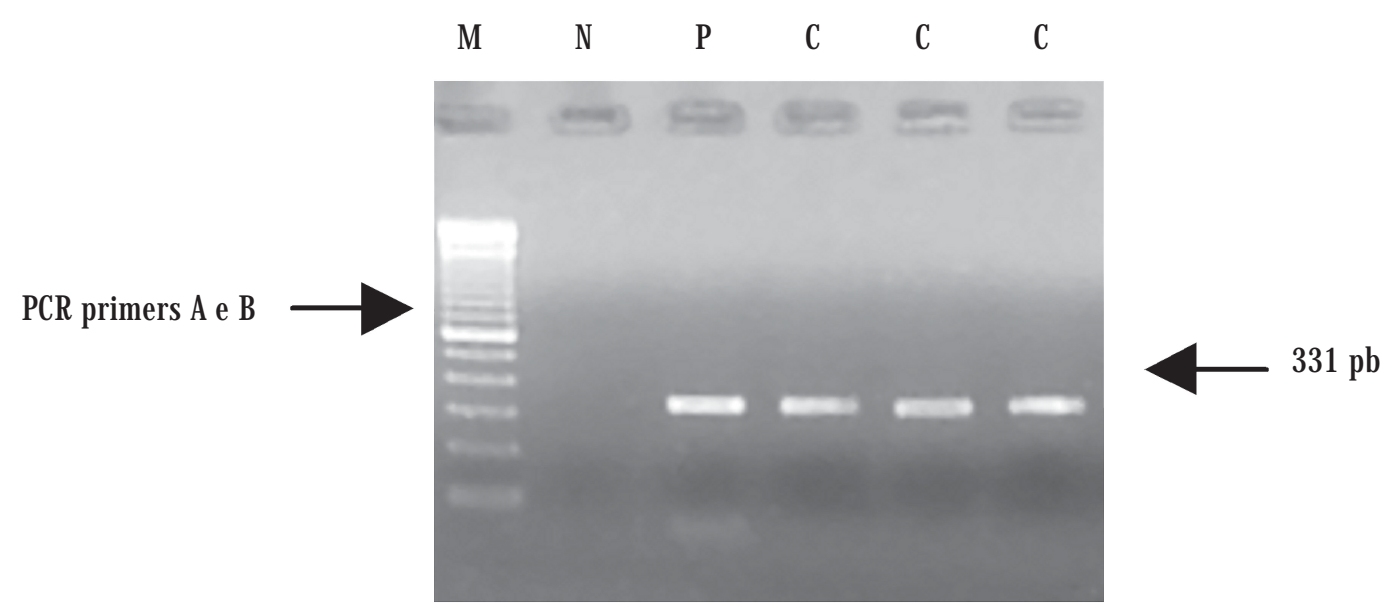

M-marcador peso molecular, N-amostra urina negativa, P- controle positivo, C-amostras de urina.

Figura 1 - Reação de PCR com três amostras de urina do cão.

Tabela 1 - Resultado da titulação sorológica de vinte amostras de 12 pacientes humanos suspeitos de leptospirose, utilizando 52 sorovares já identificados e um sorovar não identificado (Tande).

\begin{tabular}{|c|c|c|c|c|c|c|c|c|c|c|c|c|c|c|c|c|c|c|c|c|}
\hline Paciente & & 1 & & 2 & 3 & 4 & 5 & & 6 & & 7 & 8 & & & 9 & & & 10 & 11 & 12 \\
\hline DPIS & 7 & 20 & 7 & 37 & 7 & 12 & 19 & 7 & 32 & 61 & 8 & 11 & 7 & 35 & 52 & 79 & 180 & 7 & 9 & 12 \\
\hline Butembo & & & & & & & & & 100 & & & & & 50 & & & & 100 & & \\
\hline Ballum & & & & & & & 100 & & & & & & & & & & & & & \\
\hline Castellonis & & & & & & 200 & & & & & 400 & & & & & & & & & \\
\hline Canicola & & 3.200 & & 400 & 25 & 200 & 3.200 & & 100 & & 200 & 100 & & & 50 & 25 & 100 & 50 & 200 & 200 \\
\hline Grippotyphosa & & 3.200 & & & 25 & & & & & & & & & & & & & & & \\
\hline Hebdomadis & & & & 100 & & & & & & & 400 & & & & & & & & & \\
\hline Copenh. M20 & & & 50 & 100 & & & 100 & & 100 & 200 & 200 & & & & & & & & & \\
\hline Ictero. RGA & & & & & & & 3.200 & & & & & & & & & & & & & \\
\hline Ictero. Verdum & & & & & & & & & & & & 200 & & & & & & & & \\
\hline Copenh. Wijnberg & & & & & & & & & & & & 400 & & & & & & & & \\
\hline Pyrogenes & & & & & & & & & & & & & & & 25 & & & & & \\
\hline Sejroe & 25 & 3.200 & & & & 400 & & & & & & 50 & & & 50 & & & & 400 & 200 \\
\hline Hardjo & 25 & & & & & & & & & & & & & & & & & & & \\
\hline Tarassovi & & 800 & & & & 200 & & & & & & & & & & & & & & 1.600 \\
\hline Andamana & 25 & & & & 25 & & & & & & & & & & 25 & & & 100 & 200 & \\
\hline Andam. Bovedo & & & & & & & & & & 25 & & & & & & & & & & \\
\hline Buenos Aires & & & & & & & & & & 25 & & & & & & & & & & \\
\hline Patoc & & & & & & & & & 100 & & & & & & & 100 & & & 200 & 400 \\
\hline Illini & & & & 100 & & & & & & & & & & & & & & & & \\
\hline Semaranga & & & & & & & & & & & & & & & & & & 50 & & \\
\hline Hurstbridge & & & & & & & & & & 100 & & & & & & & & & & \\
\hline MaiorTitulo & 25 & 3.200 & 50 & 400 & 25 & 400 & 3.200 & 0 & 100 & 200 & 400 & 400 & 0 & 50 & 50 & 100 & 100 & 100 & 400 & 1.600 \\
\hline TANDE & 0 & 6.400 & 400 & 9.600 & 50 & 400 & 3.200 & 400 & 400 & 100 & 800 & 8.000 & 0 & 200 & 400 & 100 & 100 & 50 & 400 & 100 \\
\hline
\end{tabular}

DPIS - Dias pós início dos sintomas em que foi coletada a amostra de sangue 
anticorpos, uma vez que este ocorreu com o novo sorovar tande. Observa-se também que a precocidade em detectar um título significativo, nos pacientes 2, 6 e 9, foi respectivamente de 7, 7 e 35 dias com 0 tande, contra 37 dias para canicola, 32 dias para copenhageni M20 e 180 dias para canicola, ou seja, nos três pacientes, tande foi cinco vezes mais precoce do que os demais sorovares. Nos pacientes 4, 5 e 11, os títulos mais altos (400, 3.200 e 400) dos sorovares sejroe, icterohaemorrhagiae RGA e pyrogenes, coincidiram com os títulos de tande. Finalmente, nos pacientes 10 e 12 (16,7\% dos pacientes) , os títulos de 100 para andamana Bovedo e de 1.600 para tarassovi, superaram os 50 e 100 de tande.

Inquérito sorológico. Soros caninos: as 105 amostras de soro canino, testadas através de MAT (Tabela 2) revelaram $55(52,4 \%)$ reagentes e, quando enfrentou-se as mesmas somente com tande, encontrou-se $54(51,4 \%)$ reagentes. A sensibilidade e especificidade da cepa tande testada com a bateria de antígenos, foi respectivamente de $61,8 \%$ e $60 \%$. A prevalência de $52,4 \%$ (55/105), considerada verdadeira é semelhante à prevalência aparente de 51,4\% (54/105). Entretanto, a soma dos soros MAT positivos encontrados na bateria de antígenos padrão e com a cepa tande apresentou prevalência de 71,4\% (75/105) , quase $20 \%$ acima do percentual inicial.

Tabela 2 - Resultados de 105 amostras de soro canino testados com a bateria de antígenos padrão e o sorovar tande na MAT.

\begin{tabular}{lccc}
\hline Tande & \multicolumn{2}{c}{ MAT } & Total \\
\cline { 2 - 3 } & $\mathrm{P}$ & $\mathrm{N}$ & \\
\hline Positivos & 34 & 20 & 54 \\
Negativos & 21 & 30 & 51 \\
\hline Total & 55 & 50 & 105 \\
\hline
\end{tabular}

Razão de chances (OR) 2,43 Limite de confiança de 95\% para OR1,02 < 0R <5,81

Máxima probabilidade estimada para $\mathrm{OR}(\mathrm{MPE}) 2,41$

Limite de confiança de $95 \%$ para MPE $1.03<0 R<5.74$

risco relativo (RR) (saída: Micro=1; Exposição: tande=1)1,53

Limite de confiança de 95\% para RR 1,04 $<$ RR $<2,25$

Qui quadrado valor de $\mathrm{p}$

Năo corrigido: $4,99 \quad 0.02547819 \leftarrow$

Mantel-Haenszel: $4,94 \quad 0.02618815 \leftarrow$

Yates corrigido: $4,16 \quad 0.04149070 \leftarrow$

Calculando-se 0 coeficiente de correlação Kappa dos resultados de MAT com tande e a bateria de antígenos, encontrase um coeficiente de 0,22, o que constitui uma correlação regular na escala de valores Kappa. Contudo, como se trata da comparação de um único sorovar contra toda a bateria de antígenos, esta correlação poderia ser considerada de moderada a substancial, ou até mesmo excelente, se fosse calculada com sorovares individuais.

Dos soros caninos analisados, 55 foram reagentes na bateria de rotina no diagnóstico laboratorial, com títulos variando de 100 a 6.400, título médio de 347 e mediana de 100. Entretanto, a inclusão do sorovar tande aumentou para 750 número de reagentes com títulos entre 100 e 25.600, título médio de 1.088 e mediana três vezes maior. A inclusão de tande substitui totalmente os sorovares canicola, ballum, icterohaemorrhagiae RGA, bataviae Van Tienem e buenos aires, por apresentar título igual ou superior, e substitui parcialmente os sorovares illini, bratislava, copenhageni, icterohaemorrhagiae Kantorovic e icterohaemorrhagiae Verdum por apresentar o mesmo título sorológico (Tabela 3). A avaliação da frequiência de sorovares, considerando 0 título mais alto e/ou coaglutinações em mesmo título identificou que o sorovar Tande, isoladamente, foi capaz de detectar $72 \%$ dos soros positivos.

Tabela 3 - Sorovares leptospirais mais freqüentes na análise de 75 soros caninos positivos na MAT utilizando a bateria de antígenos padrão mais a inclusão de tande.

\begin{tabular}{|c|c|c|c|c|c|c|c|c|}
\hline \multirow[b]{2}{*}{ Sorovares } & \multicolumn{7}{|c|}{ Título de anticorpos } & \multirow[b]{2}{*}{ Total } \\
\hline & 100 & 200 & 400 & 800 & 1.600 & 6.400 & 9.60025 .600 & \\
\hline Tande & 9 & 9 & 9 & 7 & 3 & 4 & 1 & 43 \\
\hline Illini & 8 & 1 & & & & & & 9 \\
\hline Tande/Canicola & 3 & & & & & & & 3 \\
\hline Bratislava & 1 & 1 & & & & & & 2 \\
\hline Copenhageni & 1 & & 1 & & & & & 2 \\
\hline Tande/Bratislava & 2 & & & & & & & 2 \\
\hline Sejroe & 2 & & & & & & & 2 \\
\hline Autumnalis & 1 & & 1 & & & & & 2 \\
\hline \multicolumn{9}{|l|}{ Tande/Canicola/ } \\
\hline Ballum/Copenhagen & ni 1 & & & & & & & 1 \\
\hline Tande/Illini & 1 & & & & & & & 1 \\
\hline \multicolumn{9}{|l|}{ Tande/Ictero. } \\
\hline Kantorovic & 1 & & & & & & & 1 \\
\hline Ictero. Kantorovic & 1 & & & & & & & 1 \\
\hline Tande/Ictero. Verdum & n 1 & & & & & & & 1 \\
\hline Ictero. Verdum & 1 & & & & & & & 1 \\
\hline Tande/Ictero. RGA & 1 & & & & & & & 1 \\
\hline \multicolumn{9}{|l|}{ Butembo } \\
\hline Tande/Bataviae & 1 & & & & & & & 1 \\
\hline Van Tienem & 1 & & & & & & & 1 \\
\hline Bataviae Swart & 1 & & & & & & & 1 \\
\hline Total & 36 & 12 & 11 & 7 & 3 & 4 & 1 & 75 \\
\hline
\end{tabular}

\section{DISCUSSÃ0}

No caso relatado, os sinais clínicos como temperatura de $40^{\circ} \mathrm{C}$, dificuldade de movimentação do trem posterior, apatia, anorexia, dor à palpação abdominal e dos membros posteriores, diarréia sanguinolenta, vômitos amarelados, salivação sanguinolenta e necrose da borda da língua, são típicos de leptospirose ${ }^{4} 61016$. Já foi demonstrado que as leptospiras não sobrevivem por muito tempo na urina, e que a sua pesquisa direta em microscopia de campo escuro quase sempre é um procedimento diagnóstico não compensatório ${ }^{26}, 0$ que torna 0 sucesso do diagnóstico dependente do exame imediato ou da utilização de meio de transporte para isolamento. Apesar disto, mesmo não utilizando meio de transporte, conseguimos tanto visualização em microscopia de campo escuro, quanto isolamento diretamente em meio de cultura e também por inoculação em hamster, cumprindo o postulado de Koch.

0 resultado do PCR mostrando a banda de 331 pares de bases e 0 seqüenciamento indicando homologia de 100\% para os sorovares canicola e bandicoot, acrescido da morte dos hamsters inoculados, confirma a patogenicidade do isolado tande.

0 isolado tande, da primeira à terceira passagem em cultivo, não aglutinou quando enfrentado com o próprio soro 
do animal. Entretanto, na quarta passagem apresentou um título de 1.600, sendo provável esta ocorrência a presença de antígeno superficial " $\mathrm{Vl}$ ", comum nos isolados recentes, o qual bloqueia os antígenos superficiais aglutinantes, concordando com observações feitas em leptospiras recém isoladas as quais são inaglutináveis até que sejam cultivadas por algumas passagens ${ }^{31}$, sendo que na 4⿳亠丷厂 passagem do isolado, foi repetida a reação obtendo-se um título de 1.600.

Na MAT, o soro suspeito deve ser enfrentado com um número expressivo de antígenos leptospirais, entre os quais estejam representantes dos principais sorogrupos patogênicos ${ }^{9} \mathrm{e}$ de todos os sorovares comuns da localidade de ocorrência dos $\operatorname{casos}^{30}$. Os títulos de anticorpos geralmente são maiores com antígenos provenientes da região onde estão ocorrendo os surtos ou casos do que com as cepas de antígenos estocadas no laboratório ainda que do mesmo sorogrupo ${ }^{15} 28$. Portanto, um número expressivo de sorovares deve ser utilizado no teste de diagnóstico para que sejam detectados sorovares pouco comuns ou não detectados até então ${ }^{18}$. As reações de MAT podem não corresponder exatamente ao sorogrupo que causou a infecção, sendo a capacidade de predizer o sorogrupo infectante menor do que $40 \%{ }^{20}$.

É recomendável testar-se amostras pareadas de soro para comprovar a positividade da primeira amostra, pela observação da soroconversão da segunda amostra. № entanto, a avaliação de amostras pareadas de 200 pacientes suspeitos de leptospirose, evidenciou que somente 3,3\% dos pacientes aumentaram 0 título em 4 ou mais vezes na segunda amostra, sugerindo que a antibióticoterapia imediata seria um fator limitante para a soroconversão, aliada a falta do antígeno correspondente na bateria de diagnóstico, sendo que a maioria das reações de coaglutinação ocorreu com sorovares saprófitas ${ }^{11}$.

0 resultado da MAT de 12 pacientes humanos mostra que, se fosse testada a primeira amostra de soro de cada paciente com a bateria de antígenos de rotina, 7 (58,3\%) amostras seriam identificadas com título igual ou superior a 100 e com um título médio de 1:929. Porém, o mesmo teste usando o isolado como antígeno, identificaria 8 pacientes na primeira amostra de soro, com um título médio de 1.713. Considerando a amostra de soro em que o título foi igual ou maior que 100, 0 maior título encontrado com a bateria de rotina foi de $3.200 \mathrm{com}$ média de 945. Na mesma avaliação feita com 0 isolado, o maior título foi de 9.600 , com média de 2.970 , ou seja, três vezes superior. Os pacientes de números 6 ( com três amostras de soro) e 9 (com cinco amostras de soro), pelos critérios tradicionais de soroconversão, seriam considerados negativos por não alcançarem um título mínimo de 400 com a bateria recomendada pelos laboratórios de referência. Entretanto, os dois pacientes, além de um quadro clínico e epidemiológico compatível com leptospirose, apresentaram título de 400 para 0 isolado. Os pacientes de números 3 e 10, ambos com uma única coleta de sangue com sete dias de início de sintomas, apresentaram títulos de 25 e 100 para a bateria e de 50 para 0 isolado, ou seja, pelos critérios laboratoriais não seriam considerados casos de leptospirose. Entretanto, se observarmos a primeira amostra dos pacientes 1, 2, 6 e 9 (7 DPIS), todos seriam também negativos pela bateria padrão, apesar dos pacientes 2 e 6 já neste momento apresentarem título de 400 para 0 isolado.
No inquérito sorológico canino, a importância do isolado ficou mais evidente. A prevalência detectada com a bateria de rotina foi de 52,4\%, identificando 14 sorovares reagentes em maior título. Porém, quando se incluiu o isolado na bateria, esta prevalência subiu para $71,4 \%$, não havendo necessidade da inclusão de cinco sorovares ( canicola, ballum, icterohaemorrhagiae RGA, bataviae Van Tienem e buenos aires) , e parcialmente de $50 \%$ da bratislava, da icterohaemorrhagiae Verdum e da icterohaemorrhagiae Kantorovic, 33\% da copenhageni e 18\% da illini. A análise sorológica feita com a bateria de rotina (Tabela 2) revelou que $61,8 \%$ dos soros reagentes também reagiram com 0 isolado, com um risco relativo de 1,53 (com um limite de confiança de $95 \%$, $1,04<R R<2,25)$, um $\chi_{\text {Mantel-Haenszel }}^{2}$ de 4.94 e um $p=0,026,0$ que justifica estatisticamente, a importância do isolado para 0 diagnóstico em nosso ecossistema. 0 coeficiente de correlação Kappa de 0,22 do isolado com toda a bateria representa uma correlação regular, entretanto, com alguns sorovares como canicola, ballum, bataviae Van Tienem, buenos aires e icterohaemorrhagiae RGA, este coeficiente de correlação é excelente. 0 título médio de 347 com uma mediana de 100 com a bateria de rotina, contra um título médio de 1.088 e uma mediana de 200 com 0 isolado, mais uma vez reforça a importância da inclusão do isolado na bateria de diagnóstico.

Os resultados encontrados com 0 isolado, tanto no inquérito sorológico humano quanto canino, revelam que a leptospirose está presente em índices superiores aos normalmente registrados, e que o problema do diagnóstico está na limitada suspeição clínica, na falta de investigação epidemiológica para avaliar fatores de risco e no uso de uma bateria de diagnóstico com isolados locais, que apesar de ser uma recomendação internacional, não há distribuição por parte do laboratório de referência nacional de cepas brasileiras, e praticamente todos os laboratórios que trabalham com MAT, usam cepas oriundas de países como Holanda, França, Estados Unidos, Canadá, Reino Unido, entre outros, ou seja, todas originárias de países de clima frio e que apresentam uma fauna de reservatórios diferente da América do Sul. Outros pesquisadores têm identificado o mesmo problema de diagnóstico, onde em uma investigação ativa para infecção leptospiral no Hawai, encontrou-se $500 \%$ de acréscimo na incidência, quando comparada com os casos oficialmente registrados ${ }^{27}$. Do mesmo modo que em regiões onde a leptospirose é endêmica, ela pode ocorrer em 5 a 15\% dos diagnósticos de pacientes com enfermidade febri ${ }^{19}$. Estudo em Baltimore, encontrou que 16\% de 1.150 pacientes selecionados aleatoriamente de um grupo de enfermidades sexualmente transmitidas, apresentaram evidência de exposição prévia ao agente leptospira, com um paciente apresentando elevado título para IgM?

Considerando a leptospirose como uma doença comum em nosso ecossistema e, ainda que tenhamos testado um único isolado local, podemos, como A. Vanotti, concluir que: a apresentação incomum de uma doença comum é mais comum do que a apresentação comum de uma doença incomum. Cabe, portanto, um esforço na busca de novos isolados, para que seja descoberto a ponta do iceberg da leptospirose animal e humana na região sul do Estado do Rio Grande do Sul. 


\section{REFERÊNCIAS BIBLIOGRÁFICAS}

1. Almeida LP, Martins LFS, Brod CS, Germano PM. Seroepidemiologic survey of leptospirosis among environmental sanitation workers in an urban locality in the south of Brazil. Revista de Saúde Pública 1: 76-81, 1994.

2. Ávila M0. Pesquisa de anticorpos antileptospira em alunos de Medicina Veterinária da UFPel. Pelotas, 1998. Dissertação de Mestrado em Medicina Veterinária, Faculdade de Veterinária, Universidade Federal de Pelotas, Pelotas, RS, 1998.

3. Ávila MO, Furtado LRI, Teixeira MM, Rosado RLI, Martins LFS, Brod CS. Leptospiral agglutinins in dogs, in the influence area of the Center for Control of Zoonosis, Pelotas city, RS, Brazil, 1995. Ciência Rural de Santa Maria 28: 107-110, 1998.

4. Birnbaum N, Barr SC, Center SA, Schermerhorn T, Randolph JF, Simpson KW. Naturally acquired leptospirosis in 36 dogs: serological and clinicopathological features. Journal of Small Animal Practice 39: 231236, 1998.

5. Bolin CA. Diagnosis of Leptospirosis: A re-emerging disease of companion animals. Seminars in Veterinary Medicine and Surgery Small Animal 11: 166-171, 1996.

6. Cacchione RA, Cedro VCF, Bulgini MJD, Cascelli ES, Martinez ES. Leptospirosis canina en la Republica Argentina. Revista de Investigación Ganadera 14: 125-132, 1962.

7. Childs JE, Schwartz BS, Ksiazek TG. Risk factors associated with antibodies to leptospires in inner-city residents of Baltimore: A protective role for cats. American Journal of Public Health 82: 597-599, 1992

8. Dacorso Filho P. Leptospirose canina. 0 Hospital 18: 797-809, 1940.

9. Faine S. Guidelines for the control of leptospirosis. World Health Organization, Offset Publication no 76, Geneve, 1982.

10. Faine S, Adler B, Bolin C, Perolat P. Leptospira and leptospirosis. $2^{\text {nd }}$ edition. MedSci, Melbourne, Vic Australia, 1999.

11. Fernandes CPH. Espiroquetemia persistente e baixos títulos de anticorpos em sorologia pareada de casos de leptospirose humana. Dissertação de Mestrado em Medicina Veterinária, Faculdade de Veterinária, Universidade Federal de Pelotas, Pelotas, RS, 2001.

12. Furtado LRI, Fehlberg MFB, Avila MO, Teixeira MM, Rosado RLI, Martins LFS, Brod CS. Prevalência e avaliação de fatores de risco à leptospirose canina, no Município de Pelotas, R.S. Arquivos do Instituto Biológico 64: 57-61, 1997.

13. Gangadhar NL, Rajasekhar M, Smythe LD, Norris MA, Symonds ML, Dohnt MF. Reservoir hosts of Leptospira inadai in India. Revue Scientifique et Technique (International Office of Epizootics) 19: 793-799, 2000.

14. Hergt R. Meaning of serotype Patoc (biflexa complex) for the diagnosis of leptospirosis by microscopic agglutination test. Zentralblat und Bakteriology 235: 506-511, 1976.

15. Hutter ER. Leptospirosis canina. Revista de Medicina Veterinária de Buenos Aires 53: 303-312, 1972.
16. Jouglard SDD. Prevalência da leptospirose canina, fatores de risco e constituição da população no meio rural do Município de Pelotas, RS. Dissertação de Mestrado em Medicina Veterinária, Faculdade de Veterinária, Universidade Federal de Pelotas, Pelotas, RS, 1999.

17. Katz AR, Manea SJ, Sasaki DM. Leptospirosis on Kauai: investigation of a common source waterborne outbreak. American Journal of Public Health 81:1310-1312, 1991.

18. Kreissberg RA. Clinical problem solving - An abundance of options. New England Journal of Medicine 329: 413-416, 1993.

19. Levett PN. Leptospirosis: re-emerging or re-discovered disease?Journal of Medical Microbiology 48: 417-418, 1999.

20. Mcdowel A. "Do icterus epidemicus". Arquivos Brasileiros de Medicina 7: 335-345, 1917

21. Merien F, Amouriaux P, Perolat P, Baranton G, Saint Girons I. Polymerase chain reaction for detection of Leptospira spp in clinical samples. Journal of Clinical Microbiology 30:2219-2224, 1992.

22. Pereira HCP. Prevalência sorológica da leptospirose humana entre trabalhadores dos frigoríficos de matadouros com inspeção estadual do Município de Pelotas, RS. Pelotas, 1996. Dissertação de Mestrado em Clínica Médica, Faculdade de Medicina, Fundação Universidade de Rio Grande, 1996

23. Pereira HCP, Baruffa G, Brod CS, Furtado LRI, Rosado RLI, Pedot T. Leptospirose: Relato de cinco casos internados no Hospital Universitário de Rio Grande, RS. Jornal Brasileiro de Medicina 72: 110-118, 1997.

24. Piza JT, Gomes LS. Moléstia de Weil em S. Paulo. Anais Paulistas de Medicina e Cirurgia 21: 23-32, 1930

25. PrescottJ, Ferrier R, Nicholson V, Johnson K, Hoff B. Is canine leptospirosis under diagnosed in southern Ontario? A case report and serological survey. Canadian Veterinary Journal 32:481-486, 1991

26. Sasaki DM, Pang L, Minette HP. Active Surveillance and Risk Factors for Leptospirosis in Hawaii. American Journal of Tropical Medicine and Hygiene 48: 35-43, 1993.

27. Tan DSK, Welch QB. Evaluation of Leptospira biflexa antigens for screening human sera by the microscopic agglutination (MA) test in comparison with the sensitized-erythrocyte-lysis ( SEL) test. Southeast Asian Journal of Tropical Medicine and Public Health 5:12-16, 1974.

28. Thiermann AB. Canine leptospirosis in Detroit. American Journal Veterinary Research 41: 1659-1661, 1980

29. Torten M. Leptospirosis. In: Stoenner HE, Torten M, Kaplan W (eds) CRC handbook series in zoonoses, section A: bacterial, rickettsial and mycotic diseases, CRC Press, Boca Raton, Flórida, vol. I, p. 363-420, 1979.

30. Ueno K, Yanagawa R, Kida H. Presence of Vi antigen in a virulent strain of Leptospira interrrogans serovar pomona and relation of $\mathrm{Vi}$ antigens of leptospiras to resistance to leptospiricidal activity mediated by antiserum plus complement. Zentralblatt für Bakteriologie, Mikrobiologie un Hygiene 252: 557-565, 1982

31. Veronesi R, Amato Neto V, Corrêa MOA. Considerações em torno de um novo caso humano de febre canicola. 0 Hospital 46: 69-79, 1954 